Edited by Christopher Jordan

BSCRP Student/Alumni

City and Regional Planning Department

Cal Poly San Luis Obispo

\section{Learning by Doing: Community Planning in the Real World}

A six-month exercise in advance planning topics teaches students the fundamentals of planning and allows them to hone their craft on a living community - all from the confines of the classroom environment. The experience earns them an award from the California Chapter of the American Planning Association and a national award from the American Institute of Certified Planners.

It is the practice of the University to educate students and empower them with the knowledge that they will need for the rest of their lives. At Cal Poly, the process of scholarship takes the title of Learning by Doing. Students are given the opportunity to "cut their teeth" on projects and tasks that are faced by professionals. For the City and Regional Planning Department, the capstone for this process is CRP 410/411 - the Community Planning Laboratory. This course allows student to solidify their understanding of the purpose, process, and scope of planning at the community scale.

The 2003-2004 Community Planning Lab, under the direction of Professor Zeljka Howard, teamed to generate a new vision for the community of San Miguel in northern San Luis Obispo County. It was an arduous six-month process (September to March) that tested the students' skills, work ethic, and potential.

\section{THE COMMUNITY}

The community of San Miguel is located 40 miles north of the City of San Luis Obispo, along U.S. Highway 101, in San Luis Obispo County, California. It is a community of approximately 1,500 people, nestled between the highway and the bank of the Salinas River. Once a boomtown in the late 1940s with twice the population of the neighboring City of Paso Robles, San Miguel today has receded to bedroomcommunity status, and with recent development of new residential projects, is striving to become a well-balanced community.

Present-day San Miguel exists on land once inhabited by the Salinan and Chumash peoples. On July 25, 1797 Franciscan missionary Father Fermin Lasuen founded Mission San Miguel Arcangel at its current location, due to its proximity to the indigenous peoples' villages and equidistance from established missions in San Luis Obispo and San Antonio.
During infancy as a European settlement, San Miguel was an agricultural town where crops were loaded onto trains and sent out around the state and country. During World War II the nearby Army base, Camp Roberts, brought thousands of soldiers to the community. Since the conclusion of the war, the role of the Camp in the nation's defense structure has been lessened, but is still significant for the area.

San Miguel possesses valuable assets from its heritage including archeological remains, one of California's most authentic Missions, an eclectic mix of architecture, and the railroad. The community's future development and growth will clearly be enhanced by maintaining these resources to preserve the town's historical character and unique attributes.

A few small shops line the main corridor, Mission Street, including two markets, a hair salon, and a pump store. The architectural style of these buildings is eclectic yet historic, with the Mission Street corridor maintaining a feel of the community's boom era in the 1940s when the nearby Camp Roberts was in full active duty. Beyond Mission Street, the area is mostly single-family detached housing. The homes, like the stores, are old and some are in need of repair and repainting.

A periphery of rolling coastal hills frame this town that has one of the most authentic California missions, quaint neighborhoods displaying a high degree of community pride, and a small townscape of limited commercial services. Beyond the train tracks, access is limited and the hills rapidly rise from a plain of open area, creating natural barriers to San Miguel. A variety of multi-family and single-family residential projects are rising out of the dust, rapidly changing the disposition of the strictly rural eastern edge). 
Most importantly, there is a strong sense of community from within, and surrounding San Miguel. These people's drive, determination, initiative, and participation in caring for the community's development is the town's greatest asset.

\section{THE PROCESS}

In the State of California, Cities and Counties are required to adopt a general plan that lays the groundwork for all future development within its boundaries. It "expresses the community's development goals and embodies public policy relative to the distribution of future land uses, both public and private" (OPR General Plan Guidelines, 2003). These general plans are broad policy documents. In the case of San Luis Obispo County, it covers an area of 3,326 square miles and more than seven disconnected, unincorporated communities, including San Miguel. It is impossible, therefore for one general plan to include the detailed desires and aspirations of all communities. For this reason, jurisdictions have the ability to adopt community plans - similar to general plans in structure and scope, but more detailed and specific.

In draft a Community Plan for San Miguel, the students followed a path similar to the proven Oregon Comprehensive Community Visioning Process (fig 1). Under the model, students researched the existing characteristics of the community and the potential future given existing trends. These findings were collected over a three month period and published as a background report. The information was then synthesized and used as a basis for a series of visioning exercises that lead to a concrete set of vision statements and an action plan (the Community Plan).
Figure 1. The planning process for the San Miguel Community Plan

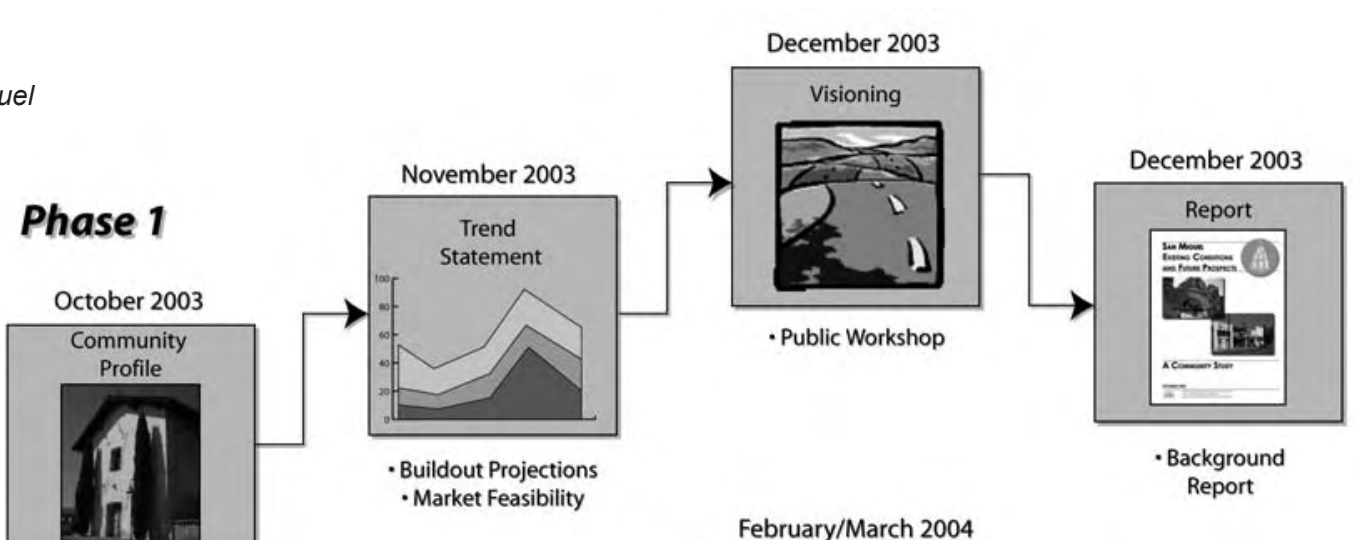

February/March 2004

- Existing Conditions - Case Studies

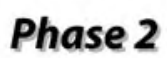

Phase 2
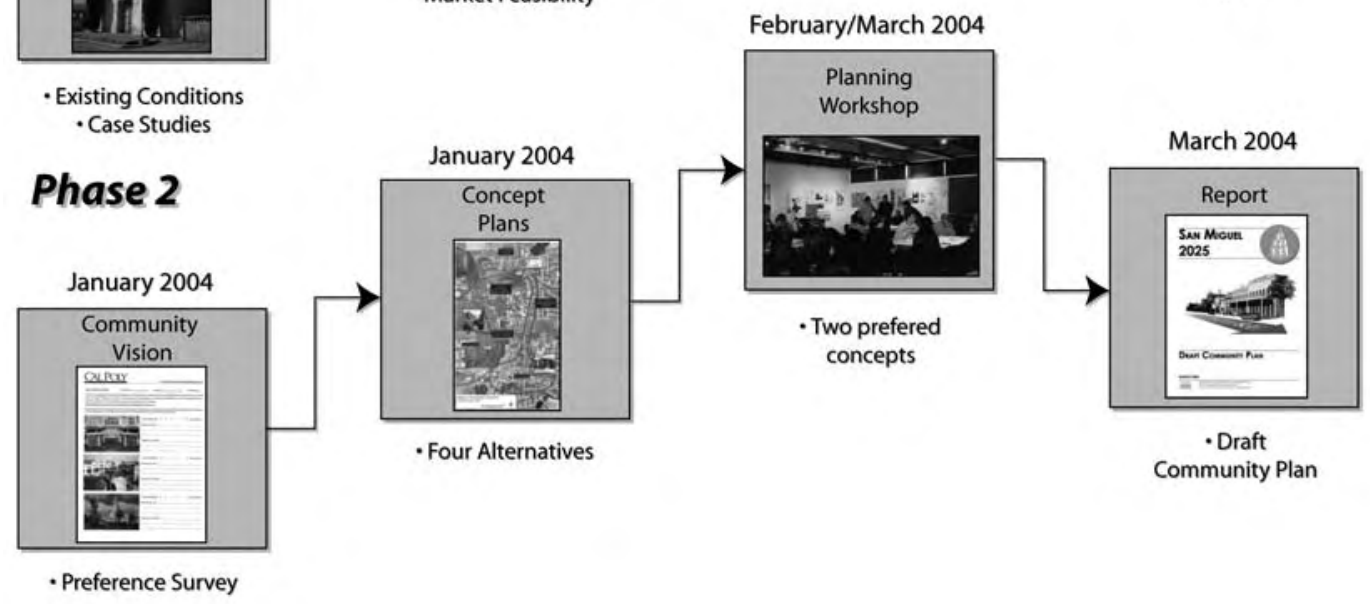
The Community Plan provides guidelines for the future physical development of San Miguel for the next 20 years of development (2004 to 2025). The plan recognizes the social and economic values of San Miguel residents, and translates these values into goals and policies, which will be used to coordinate public and private sector development, creating a vibrant and attractive community. It offers recommendations for future development and establishes development standards and actions needed to bring the community's vision of the future to fruition. It identifies the community's land use, circulation, environmental, economic, and social goals and policies as they relate to future growth and development and provides a basis for local government decision-making, including decisions on development approvals and exactions, and provides citizens with opportunities to participate in the planning and decision-making processes of their community.

\section{COMMUNITY INVOLVEMENT}

Community involvement and interaction is a vital component of the planning process. To involve the community in the development of the San Miguel Community Plan, a variety of surveys, interviews, community workshops, and planning and design charrettes were conducted. Flyers, newspaper articles, radio and television announcements were among the types of media used to promote community involvement. A "community banner," an electronic community newsletter, assisted in increasing resident awareness for both the public workshop and the planning and design charrette.

In December 2003, the first Public Workshop was held. The preliminary research of the existing conditions of San Miguel was presented and the community was asked for feedback. The participants were involved in identifying key issues of major concern throughout their community. After the presentation a question/answer session was held and a list of general concerns not necessarily related to a specific part of the research.

A series of surveys were previously conducted in San Miguel in 1979, 1988, 1996, and 2002, providing information which students incorporated into the San Miguel Community Plan. As part of the students' research, an Environmental Cognition Study and Visual Preference Survey were conducted in January 2004. The purpose of these activities was to involve the community by surveying residents, businesses, and visitors of San Miguel to understand their visual image of future development in the community.

In February 2004, the students held two workshops. The first was a Planning and Design Charrette held on the Cal Poly campus. Charrette participants included representatives from the San Miguel Advisory Body, local property owners, San Luis Obispo County planning staff, and students from a graduate planning class developing proposals for a specific property in San Miguel. The second workshop was held in San Miguel, where the community had an opportunity to discuss and select a concept plan that best reflected their vision of their community.
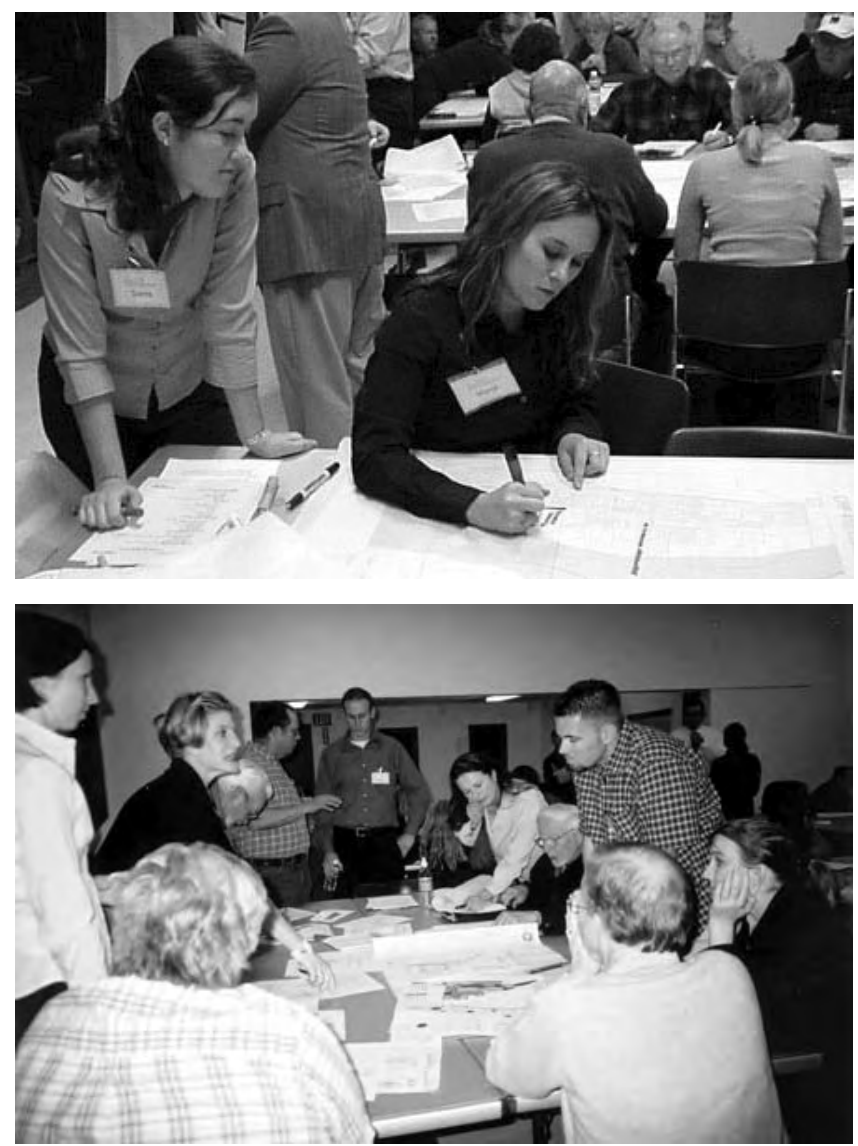

Figure 2. Students and residents at the public workshops 


\section{THE PLAN}

The final Draft Community Plan attempted to incorporate many of the community's needs and desires. It included discussion on several key topics, including land use, housing, economic development, urban design, circulation and public facilities, parks, recreation, and community services, and open space, conservation, noise, safety, and air quality. It also provided a land use diagram that describes the general location of land uses within the community. Central in the plan were six overall goals for community development:

- Promote the stimulation of the local economy through the creation of tourism activities and a vibrant downtown of economic and visual continuity.

- Create linkages between San Miguel's mission and its historic heritage with all existing and new development, services, and activities.

- Manage growth in a responsible manner addressing resident needs and desires while adequately balancing population increase with the capacity to meet heightened demand for public services.

- Enhance community character through a healthy balance of land uses and adequate provision of services and facilities to improve the quality of life for all residents.

- Centralize, limit, and direct the focus of development to allow for the creation of a vital town center and unique town identity.

- Preserve all resources sensitive to community expansion including natural, historic, or agricultural features that will improve the quality of life for residents through their continued existence.

These goals were the basis for three distinct and interrelated visions: A Vision for Growth; A Vision for Tourism; and A Vision for a Balanced Community.

\section{A VISION FOR GROWTH}

County growth pressures will inevitably affect San Miguel significantly by 2025 . The San Miguel Community Plan includes a vision for growth to better manage development

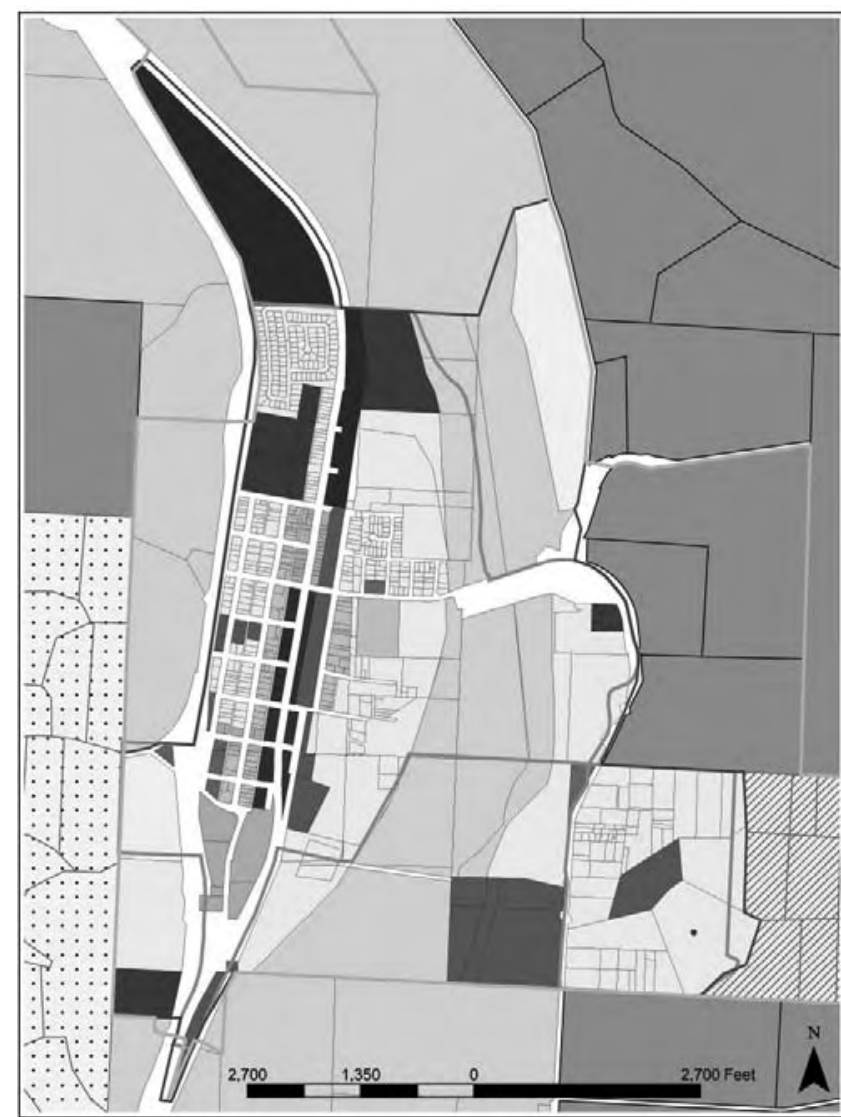

Figure 3. Land Use Map for San Miguel

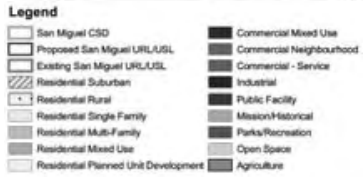

patterns while meeting community needs. Facilitating growth rather than ignoring it will enhance the environment of the community and channel development to appropriate locations and in an appropriate manner, so that San Miguel may preserve its cherished small town character.

\section{A VISION FOR TOURISM}

San Miguel will become a place for tourists. Visitors will be attracted to the historic Spanish Mission and to the many area wineries. San Miguel will undergo numerous improvements throughout its downtown reflecting economic growth based 


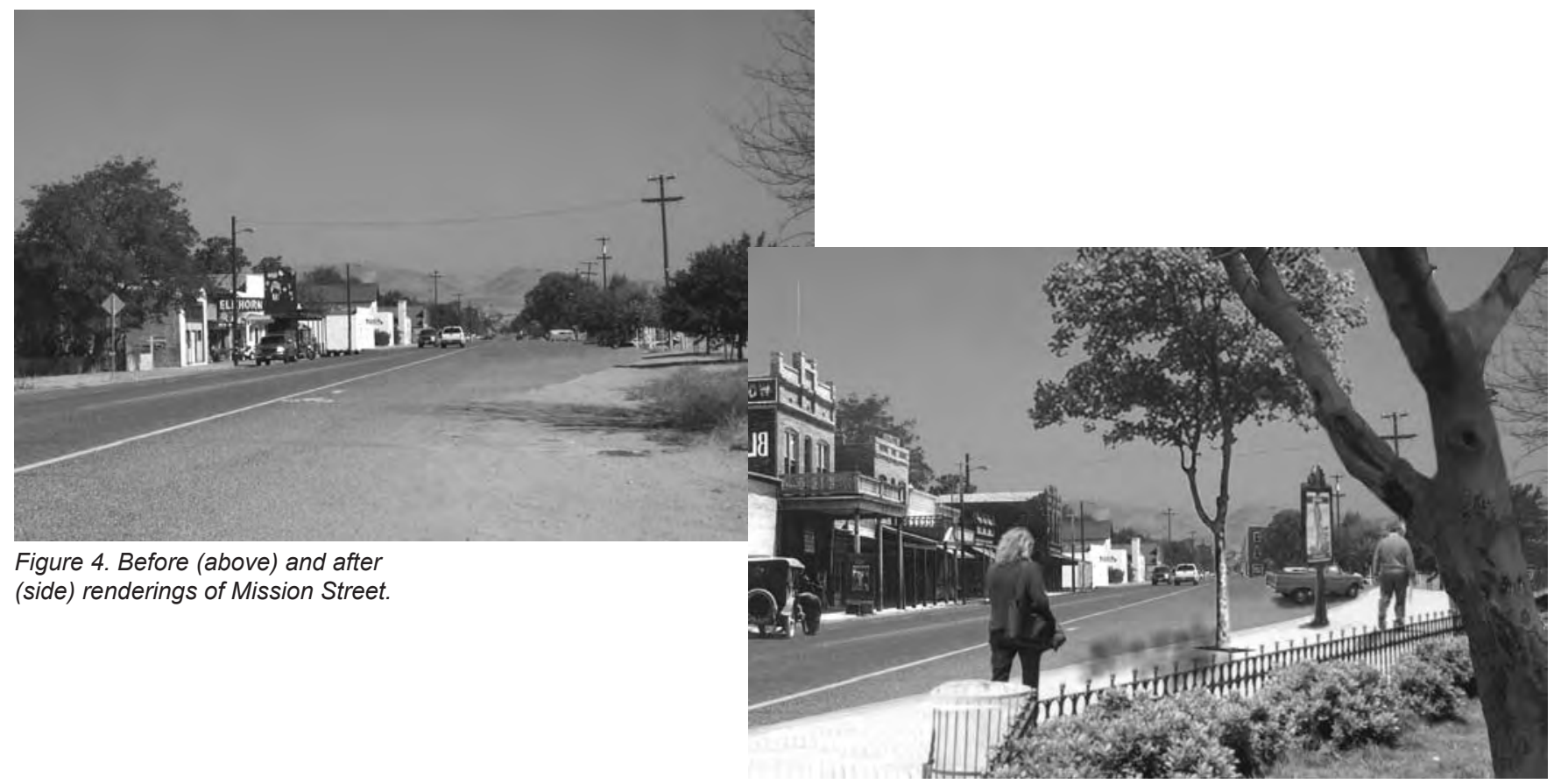

on a successful ability to attract visitors to the community. As a result, a thriving downtown core will emerge to provide a variety of commercial developments including mixeduse and tourist oriented services. A pedestrian friendly environment will allow easy access to both the commercial and historical features of the community. The benefits of the success of the tourism industry will extend to residents by providing them additional opportunities to live and work in San Miguel.

\section{A VISION FOR A BALANCED COMMUNITY}

The greatest achievement foreseen for San Miguel in 2025 will be its ability to finally act as a healthy and balanced community. Being healthy means providing people with stores, activities, and, most of all, community facilities and housing opportunities meeting the needs of a diverse population.

After-school hangouts for youth will be provided with a skate park, also containing snack stands and other youth-oriented activities. Recreation will be available for adults too, with an equestrian facility and trails linking the Salinas River to all areas of the community. Not only do these trails attract visitors to the area, they act as a community link, making available the option of walking from the east side of the Salinas River to the west side.

San Miguel community members will frequently choose to walk to town. Spending time with fellow neighbors will be common in San Miguel. With a weekly farmers market and the closure of K Street at the community park on the weekends, community activities will frequently occur further strengthening the bond between San Miguel residents.

\section{LESSONS LEARNED}

The preparation of the Community Plan provided a valuable experience for the students. It provided them with the opportunity to advance their skills and learn vital planning procedures and techniques for use in the real world in the classroom environment. The course is structured to simulate the professional planning work environment; however it is not a perfect simulation, as the class does not have access to a broad range of information sources nor does it have the well defined management levels of a professional planning office. This process has been, and continues to be, one of learning for the students. Additionally, the short time frame leaves 
little room for advanced research and intense community discussion of ideas as would normally be incorporated into a project such as this.

Despite these limitations, the final product has won numerous praise and accolades from the community and fellow planners. Both the California Chapter of the American Planning Association and its Central Coast Section have awarded it top honors for outstanding leadership by an academic institution and the American Institute of Certified Planners awarded it Best Student Project at the National American Planning Association conference in March 2005.

\section{NOTES}

Project participants:

Brian Allee, Sarah Behm, Michael Conger, Michelle Glueckert, William Heppler, Christopher Jordan, Cornelius Kempenaar, Alexa Lawrence, Brian Levielle, Michael McKay, Eric Muzzy, Nicholle Narhi, Mandi Raike, Jennifer Rocci, Jason Rogers, Sierra Russell, Simon Santiago, Heather Smith, and David Stanfield.

Project Advisor: Professor Zeljka Howard

For more information on the San Miguel Draft Community Plan, contact the City and Regional Planning Department or visit the project website at planning.calpoly.edu/projects/ sanmiguel. 